\title{
PENGELOLAAN MATA AIR UNTUK PENYEDIAAN AIR RUMAHTANGGA BERKELANJUTAN DI LERENG SELATAN GUNUNGAPI MERAPI (Springs Management for Sustainability Domestic Water Supply in the South West of Merapi Volcano Slope)
}

\author{
Sudarmadji $^{1 *}$, Darmakusuma Darmanto ${ }^{1}$, Margaretha Widyastuti ${ }^{1}$ dan Sri Lestari $^{2}$ \\ ${ }^{1}$ Fakultas Geografi, Universitas Gadjah Mada, Sekip Utara, Yogyakarta 55281. \\ ${ }^{2}$ Fakultas Biologi, Universitas Jenderal Soedirman, Jl. dr. Soepeno 63, Purwokerto 53122.
}

*Penulis korespondensi. Tel: 0274-649 2347. Email: sudarmadji@geo.ugm.ac.id.

Diterima: 26 Mei 2015

Disetujui: 22 September 2015

\begin{abstract}
Abstrak
Mata air merupakan pemunculan air tanah ke permukaan tanah. Pemanfaatan mata air sangat beragam, antara lain penggunaan untuk keperluan air minum, irigasi, perikanan, untuk obyek wisata. Mata air mempunyai debit terbatas, namun kualitasnya baik, penggunaannya beragam, hal tersebut sering terjadi konflik pemanfaatan. Di saat musim kemarau, beberapa mata air merupakan sumber air satu-satunya di suatu tempat, sehingga pengelolaannya harus dilakukan secara baik. Penelitian ini bertujuan untuk mempelajari pengelolaan mata air berbasis teknologi tepat guna dalam penyediaan air rumahtangga di lereng selatan Gunungapi Merapi. Penelitian dilakukan dengan survei dan observasi di lapangan terhadap mata air yang digunakan untuk penyediaan air rumahtangga. Sejumlah responden pengguna mata air dan tokoh masyarakat setempat diwawancarai secara bebas dan terstruktur untuk memperoleh data pengelolaan mata air. Hasil penelitian menunjukkan bahwa kondisi lingkungan dan karakteristik mata air, pengetahuan masyarakat dan budaya lokal yang beragam akan berpengaruh terhadap pengelolaanmata air. Perkembangan teknologi tidak dapat diabaikan dalam pengelolaan sumberdaya air. Hal ini dapat dipadukan dengan budaya masyarakat setempat dalam pengelolaan mata air, sehingga dapat diperoleh manfaat yang optimal dan kesinambungan fungsi dan manfaat mata air tersebut.
\end{abstract}

Kata kunci: kearifan lokal, mata air, pengelolaan, teknologi tepat guna.

\begin{abstract}
Spring is the groundwater which comes out on ground surface. The use of water from springs is very diverse, varying from water for drinking, irrigation, fisheries, even for tourism. The springs usually have a limited discharge but the water quality from springs is good, therefore they are often facing some conflicts in utilization. In the dry season, in fact the springs are the only source of water supply; therefore the management of the spring should be done properly. This research aims to study the spring management based on appropriate technology in relation to household water supply in the southern slopes of Merapi Volcano. The study was conducted using survey and observation methods. A number of respondents were drawn from community who are using spring and local community leaders. Some were interviewed using depth interview and some were interviewed using questioner to obtain data on spring management. The results showed that environmental conditions, characteristics of the springs, the knowledge of the society and local culture affect the management of the springs. The development of technology cannot be ignored in the water resources management (including from spring). It can be combined with the culture of local communities in the management of springs, to obtain optimum benefit and the sustainability of these springs.
\end{abstract}

Keywords: appropriate technology, local knowledge, management, spring.

\section{PENDAHULUAN}

Air merupakan kebutuhan mutlak bagi kehidupan manusia, tidak ada kehidupan yang dapat berlangsung tanpa air. Kebutuhan manusia akan air diperoleh dari berbagai macam sumber, baik yang berupa air hujan, air permukaan maupun air tanah. Kebutuhan air dari air tanah antara lain dapat diperoleh dari mata air, yang merupakan pemunculan air tanah ke permukaan tanah (Todd, 1980). Kebutuhan air yang diperoleh dari mata air sangat nyata dirasakan ketika terjadi musim kemarau panjang. Banyak daerah yang pada musim tersebut telah kehabisan air dari sumber air, tetapi mata air seringkali masih menyediakan air untuk digunakan bagi kepentingan sehari-hari. Banyak tempat pada musim kemarau hanya mengandalkan mata air, walaupun penduduk harus menempuh jarak yang sangat jauh untuk mendapatkan air tersebut. Seringkali untuk mendapatkan air tersebut bahkan harus antri, tetapi tetap saja dilakukannya. Dapat dikatakan dalam kondisi semacam ini mata air merupakan "penyelamat" bagi masyarakat yang kekurangan air. 
Mata air yang terletak di bagian hulu suatu daerah tidak hanya memasok air untuk daerah sekitarnya, tetapi juga dapat digunakan untuk memenuhi kebutuhan air daerah di hilir. Dengan keadaan seperti ini diperlukan teknologi untuk mendistribusikan air ke konsumen di bagian hilir secara bijaksana agar tidak terjadi konflik pemanfaatan air mata air tersebut. Mata air merupakan pemunculan air tanah ke permukaan tanah karena muka air tanah terpotong, sehingga di titik tersebut air tanah keluar sebagai mata air atau rembesan. Mata air mempunyai debit yang bervariasi dari debit yang sangat kecil $<10 \mathrm{~mL} /$ detik hingga yang sangat besar $10 \mathrm{~m}^{3} /$ detik (Todd dan Mays, 2005). Dengan variasi debit yang sangat besar dapat diduga bahwa penggunaan air mata air inipun sangat bervariasi. Apalagi kalau dilihat dari aspek kualitasnya, mata air dapat mempunyai kadar zat kimia yang sangat tinggi dan dapat dimanfaatkan sebagai sumber pengobatan. Di sisi lain juga banyak mata air yang mempunyai kualitas yang sangat baik, sehingga banyak dimanfaatkan untuk air minum atau bahan baku air minum.

Mata air yang bersumber atau berada di daerah gunungapi seringkali mempunyai kualitas yang sangat baik, sehingga banyak dimanfaatkan untuk penyediaan air minum atau bahan baku air minum bagi penduduk di sekitarnya atau penduduk di daerah hilirnya. Pada waktu kebutuhan air masih terbatas, maka air dari mata air kebanyakan hanya mengalir begitu saja, belum sepenuhnya dimanfaatkan, atau kalau dimanfaatkan hanya sebatas untuk keperluan irigasi atau perikanan. Pada saat penduduk semakin banyak jumlahnya dan daerah di bagian hilir berkembang, maka mata air tersebut dimanfaatkan lebih jauh untuk pemenuhan kebutuhan air rumahtangga. Pengaturan pembagian air melalui pembatasan debit yang dialirkan dapat juga menjadi pertimbangan dalam pemakaian air untuk kebutuhan domestik di daerah pedesaan, seperti penelitian yang dilakukan oleh Fan dkk., (2014).

Konservasi menurut Randall (1982) merupakan alokasi sumberdaya antar waktu yang optimal secara sosial. Secara umum konservasi merupakan pengelolaan sumberdaya secara bijaksana untuk menjamin kesinambungan persediaannya dengan tetap memelihara dan meningkatkan kualitas nilai. Upaya konservasi akan berjalan dengan baik jika ada kerjasama pemerintah dan masyarakat. Kearifan lokal dalam upaya pelestarian sumberdaya air di suatu wilayah sangat diperlukan. Pada taraf pelaksanaannya, kearifan lokal dapat dilihat dari partisipasi masyarakat dalam mengelola sumberdaya air. Faktor pengetahuan dan sikap adalah bagian penting dalam perilaku, oleh karena hal tersebut berpengaruh terhadap besar kecilnya partisipasi.

Pemanfaatan mata air ini seringkali menimbulkan konflik kepentingan; namun demikian masyarakat Gunungapi Merapi memiliki kearifan lokal, yang apabila kearifan lokal ini dapat dipadukan dengan teknologi tepat guna akan dapat digunakan untuk mengelola sumberdaya alam secara berkelanjutan (Sudarmadji dkk., 2010). Selanjutnya Sudarmadji dkk., (2012) dan Sudarmadji, 2013), mengkaji mata air dalam hidrologi dan perspektif lingkungan, termasuk budaya masyarakat dalam mengkonservasi mata air, dan pemanfaatannya untuk berbagai keperluan. Cara masyarakat untuk menjaga agar kondisi mata air dari sisi kuantitas maupun kualitasnya, antara lain melalui upacaraupacara adat, anggapan mata air sakral dan keramat. Teknologi selalu berkembang, tetapi pada satu sisi masyarakat berpegang kepada budaya lokal. Untuk memadukan perkembangan teknologi dan kearifan lokal di dalam mengelola mata air, memerlukan pengkajian lebih mendalam (Sudarmadji dkk., 2014). Kajian yang serupa yang dilakukan oleh Siswadi dkk. (2011) mengenai kearifan lokal dalam melestarikan mata air (Tuk Serco) di Desa Purwogondo, Kecamatan Boja, Kabupaten Kendal. Mata air tersebut dimanfaatkan untuk kebutuhan domestik dan irigasi sebesar 50,71\% dari debit yang tersedia 12,93 L/det, sedangkan sisanya 49,29\% belum terpakai. Kearifan lokal penduduk di Desa Purwogondo berupa pengetahuan, nilai-nilai, etika, moral dan norma (anjuran, larangan, sanksi dan ungkapan) sebagai pedoman dalam menjaga sikap dan perilaku dalam memelihara, menjaga dan melestarikan mata air Tuk Serco.

Masyarakat daerah pedesaan banyak memanfaatkan air untuk keperluan rumahtangga yang bersumber dari mata air. Mata air yang debitnya relatif kecil umumnya dimanfaatkan oleh masyarakat setempat, tetapi mata air yang berdebit besar umumnya telah dimanfaatkan oleh pemerintah untuk penyediaan air minum atau oleh perusahaan untuk memenuhi keperluannya (Sudarmadji dkk., 2012). Penelitian ini bertujuan untuk menginventarisasi potensi mata air daerah Lereng Baratdaya Gunungapi Merapi untuk kebutuhan air rumahtangga dan mengkaji cara pengelolaan mata air oleh masyarakat setempat.

\section{METODE PENELITIAN}

\section{Lokasi Penelitian}

Penelitian ini dilaksanakan di Daerah Lereng Selatan Gunungapi Merapi, meliputi 2 (dua) kecamatan, yaitu Kecamatan Turi dan Kecamatan Pakem, Kabupaten Sleman. Mata air yang dipilih 
adalah mata air yang penggunaan utamanya untuk keperluan rumahtangga masyarakat setempat dan masyarakat di bagian hilirnya. Mata air yang diteliti adalah mata air yang pengelolaannya dilakukan oleh masyarakat setempat, bukan oleh pihak pemerintah daerah atau oleh perusahaan.

\section{Bahan dan Alat}

Bahan yang diperlukan dalam penelitian ini adalah peta mata air yang sudah ada berdasarkan hasil penelitian terdahulu. Peralatan yang digunakan meliputi GPS untuk mengetahui posisi geografi dari mata air terpilih, kuesioner untuk wawancara dengan penduduk maupun tokoh masyarakat setempat, kamera dan recorder untuk mendokumentasi hasil wawancara dan pengukur debit.

\section{Sampel}

Sampel responden diambil menggunakan teknik purposive sampling, merupakan teknik pengambilan sampel dengan pertimbangan bahwa sampel yang diambil telah diketahui sifat-sifatnya yang sesuai dengan permasalahan dan tujuan penelitian. Populasi dalam penelitian ini adalah masyarakat pengguna air mata air. Respondennya adalah masyarakat yang melakukan pengelolaan mata air, yang tinggal berdekatan dengan mata air, dengan jumlah sampel 30. Selain itu diambil tokoh masyarakat sebagai responden untuk wawancara mendalam.

\section{Pengumpulan Data}

Data yang berkaitan dengan pengelolaan mata air dikumpulkan melalui wawancara, sedangkan data kondisi mata air dikumpulkan melalui observasi dan pengukuran debit serta pengambilan sampel air. Wawancara dilakukan dengan cara terstruktur menggunakan kuesioner sebagai panduannya. Wawancara ini dilakukan untuk mendapatkan informasi yang lebih jelas dan mendalam tentang partisipasi masyarakat terhadap keberadaan dan upaya pelestarian mata air yang secara langsung bermanfaat untuk mencukupi kebutuhan hidup.

Depth interview dilakukan terhadap tokoh masyarakat dan pejabat daerah untuk mengetahui kebijakan dan kegiatan yang direncanakan oleh masyarakat setempat dalam hal pemanfaatan dan konservasi mata air air guna memenuhi kebutuhan masyarakat setempat maupun masyarakat di daerah hilirnya.

\section{Pengolahan dan Analisis Data}

Pengolahan dan analisis data diawali melalui proses pemilahan, penyederhanaan dan transformasi data kasar. Hasil wawancara dengan responden ditabulasi untuk pemberian kode. Proses selanjutnya adalah pengelompokan informasi yang sama dari jawaban responden untuk membuat suatu simpulan mengenai pemanfaatan dan konservasi mata air. Analisis dilakukan untuk mengkaitkan hasil observasi dengan hasil wawancara dalam pengelolaan mata air, termasuk pemanfaatan teknologi tepat guna dan budaya masyarakat setempat.

\section{HASIL DAN PEMBAHASAN}

\section{Karakteristik Mata Air}

Mata air sebagai bentuk pemunculan air tanah sangat banyak dijumpai di daerah penelitian. Mata air muncul pada perubahan lereng (break of slope) dan banyak juga yang muncul karena muka air tanah terpotong oleh lembah sungai. Mata air yang muncul karena muka air tanah terpotong oleh lembah banyak didapati di tebing atau pinggir sungai. Pemunculan mata air seringkali terdapat pada tempat-tempat yang sulit untuk dijangkau, sehingga untuk memanfaatkan mata air tersebut diperlukan suatu cara untuk mempermudah mendapatkan air dari mata air tersebut. Pemunculan mata air tidak selalu mudah dapat teridentifikasi, karena selain yang berupa titik dan ada juga yang berupa garis atau bahkan area. Mata air yang disebutkan belakangan agak sulit untuk diidentifikasi apalagi untuk diukur debitnya. Lokasi mata air yang diteliti ditunjukkan pada Gambar 1.

Mata air yang ditemukan di lapangan mempunyai debit yang bervariasi, dari kurang 1 liter per detik sampai lebih dari 50 liter/detik. Hasil pengukuran debit mata air yang 1 tersebut hanya dilakukan sesaat. Artinya bahwa debit mata air tersebut mungkin tidak konstan sepanjang tahun. Pada musim kemarau debit mata air dapat menyusut, bahkan beberapa mata air pada musim tersebut tidak lagi mengalirkkan air, tetapi sebaliknya pada musim penghujan debit mata air tersebut dapat bertambah besar dari debit yang terukur.

Penelitian mata air di Kecamatan Turi dan Kecamatan Pakem dilakukan mulai bulan Juli 2012, dilanjutkan sampai tahun 2014 dengan mengambil sampel pada beberapa mata air. Analisis di laboratorium dilakukan untuk mengetahui kondisi kualitas airnya, meliputi Kalsium (Ca), Magnesium (Mg), Kesadahan $\left(\mathrm{CaCO}_{3}\right)$, Besi total (Fe), Natrium $(\mathrm{Na})$, Kalium $(\mathrm{K})$, Sulfat $\left(\mathrm{SO}_{4}\right)$, Klorida $(\mathrm{Cl})$ dan Kebasaan $\left(\mathrm{HCO}_{3}\right)$. Hampir seluruh parameter tersebut masih berada di bawah Baku Mutu air atas dasar Permenkes 416/MENKES/KES/IX/1990, hanya satu unsur yaitu Kesadahan $\left(\mathrm{CaCO}_{3}\right)$ di Bangunmulyo menunjukkan angka $600 \mathrm{mg} / \mathrm{L}$ yang sebaiknya di bawah $500 \mathrm{mg} / \mathrm{L}$, sedangkan di lokasi 


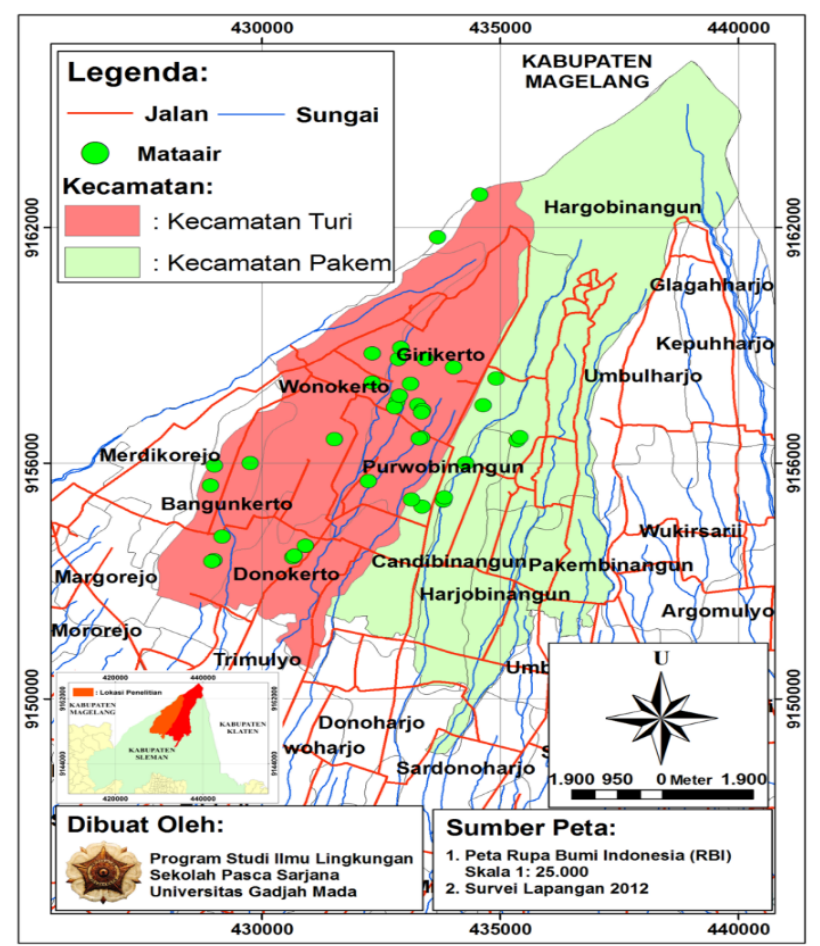

Gambar 1. Lokasi mata air yang diteliti.

yang lain sebagian besar berada pada angka antara 106 mg/L sampai 404 mg/L di bawah angka Batu Mutu air. Unsur Klorida (Cl) dan Sulfat $\left(\mathrm{SO}_{4}\right)$ untuk semua lokasi masih sangat jauh dari batas Baku Mutu air yang berlaku yaitu antara 3,27-38,78 mg/L untuk Sulfat dan 18-28 mg/L untuk Klorida, yang seharusnya batas Baku Mutu airnya 400 mg/L untuk Sulfat dan 600 mg/L untuk Klorida.

\section{Pemanfaatan Mata Air}

Mata air yang banyak didapatkan di daerah ini dimanfaatkan untuk berbagai keperluan, baik untuk keperluan rumahtangga, irigasi dan. Dalam memenuhi kebutuhannya masyarakat menggunakan air mata air untuk mandi dan mencuci, ada yang dapat dilakukan di tempat pemunculan mata air dengan membangun tempat mandi dan mencuci. Untuk keperluan masak dan untuk air minum, masyarakat menggunakan pipa untuk menyalurkan air ke dalam rumahnya. Letak mata air yang airnya disalurkan untuk keperluan ini biasanya jauh di hulu. Dalam menggunakan air dari air mata air untuk keperluan rumahtangga (domestic use), sebagian masyarakat menggunakan air langsung dari sumbernya dan menggunakannya di tempat pemunculan mata air. Sebagian ada yang harus menampungnya lebih dahulu, baru menggunakan nya, bahkan ada yang sebelum menggunakan air tersebut harus menampungnya,menyalurkan dan kemudian baru menggunakannya (Gambar 2).

Keuntungan dalam penggunaan air dari mata air adalah masyarakat tidak memerlukan biaya untuk

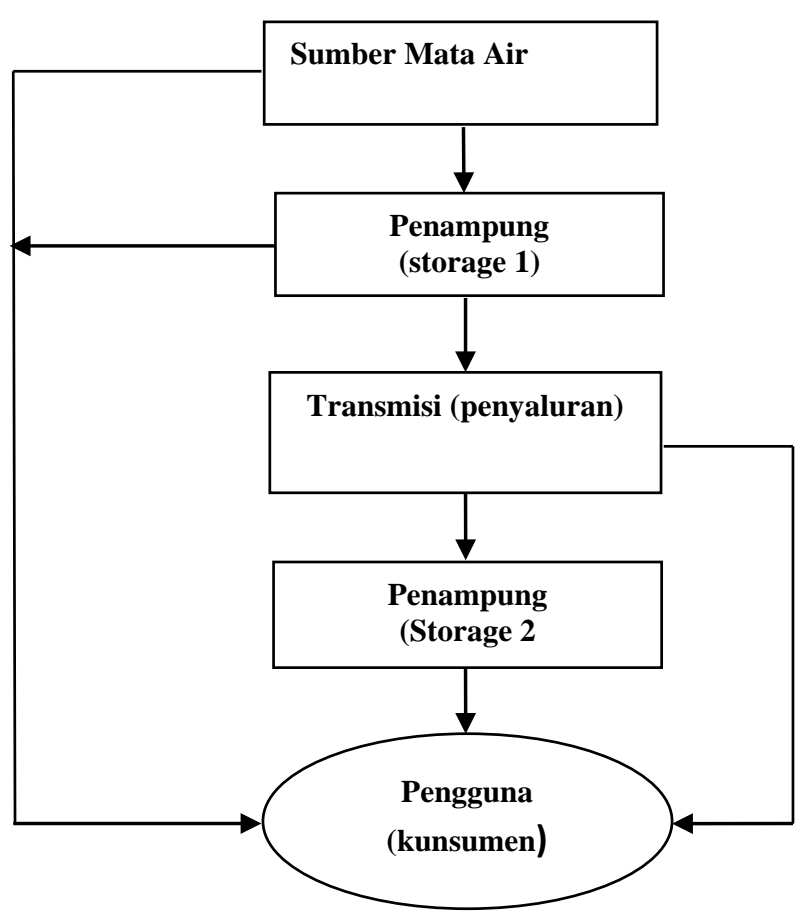

Gambar 2. Sistem distribusi air dari sumber ke pengguna.

pemompaan seperti kalau menggunakan air tanah dari sumur. Beaya yang dikeluarkan hanya biaya untuk iuran, yang digunakan untuk pemeliharaan, seperti untuk biaya penggantian dan perbaikan pipa kalau terjadi kerusakan. Peranan mata air sebagai sumber penyediaan air rumahtangga sangat penting. Kesinambungan air dari mata air lebih terjamin dibandingkan dengan air permukaan, karena pada musim kemarau panjang beberapa mata air masih cukup menyediakan air, sedangkan sungai sudah kering.

\section{Teknologi dalam Pemanfaatan Mata Air}

Mata air yang banyak didapatkan di daerah ini sangat baik dan menguntungkan dari sisi kualitas. Air yang keluar sebagai mata air di daerah perubahan slope maupun di tepi sungai merupakan sumber air yang banyak digunakan oleh masyarakat setempat, bahkan oleh masyarakat di daerah hilirnya. Mata air tersebut tidak begitu saja dapat dimanfaatkan. Beberapa cara untuk memanfaatkan air mata air dilakukan sesuai dengan kondisi mata air tersebut dimulai dari tempat munculnya mata air sampai kepada konsumen. Tempat pemunculan mata air secara alami biasanya tidak mudah untuk dijangkau, sehingga diperlukan teknologi dalam memanfaatkan mata air tersebut, seperti diuraikan berikut ini.

\section{Penampungan air mata air}

Untuk dapat memanfaatkan mata air masyarakat membuat bangunan pengumpul mata air untuk 
menampung air mata air. Banyak mata air yang terdapat di daerah ini ditampung dengan bangunan penampung. Bangunan penampung tersebut dapat bersifat terbuka maupun tertutup. Bangunan yang tertutup memudahkan untuk menampung dan menyalurkannya ke daerah hilir. Dengan membuat penampungan dengan menutupnya dengan bak penampung, maka mudah bagi masyarakat untuk menyalurkannya ke daerah hilir. Selain berfungsi untuk menampung air sebelum disalurkan ke konsumen bangunan ini berfungsi juga untuk melindungi air dari pencemaran. Penampung air ini sangat bermanfaat untuk menampung air yang keluar sebagai rembesan (seepage). Dalam prakteknya dalam membuat ukuran penampung tidak secara pasti dilakukan pengukuran debit oleh masyarakat setempat, tetapi bukan berarti di dalam perencanaannya debit mata air tidak diperhatikan. Masyarakat setempat sudah memperhitungkan debit mata air. Semakin besar debit mata air, semakin besar ukuran penampung yang sudah dibuatnya. Penampung tersebut ada yang bebentuk kotak atau kubus, ada yang berbentuk silender dengan ukuran yang bervariasi, disesuaikan dengan kondisi mata air. Apabila mata air tidak hanya muncul di satu titik, seringkali dibuat beberapa penampung, dan antara penampung satu dengan lainnya dihubungkan, sehingga air dari penampung yang satu dapat mengalir ke penampung yang lain (Gambar 4). Dalam perancangan bangunan penampung sudah diperhitungkan debit mata air dan kebutuhan rumah
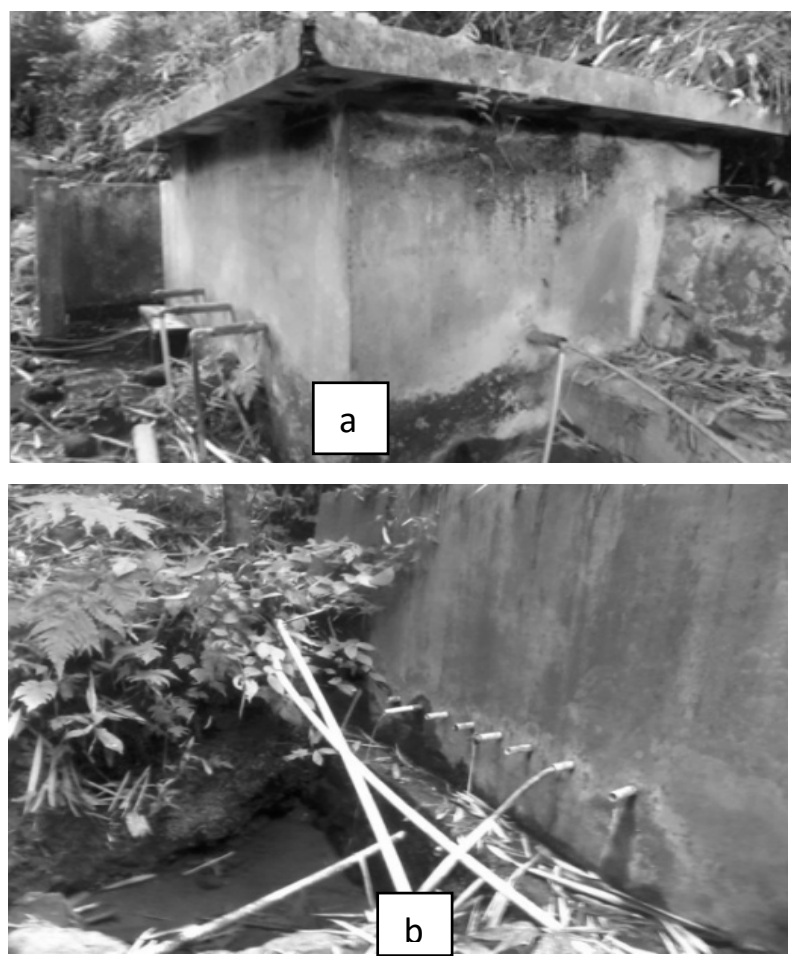

Gambar 3. Penampungan air dari mata air (a). penampungan bentuk kubus, (b) titik outlet untuk menyalurkan air. tangga. Perkiraan debit mata air tersebut berdasarkan atas pengalaman dan pengamatan dari mata air yang airnya ditampung, termasuk kesinambungan dari aliran air dari mata air tersebut.

Bahan yang digunakan untuk membuat bak penampung sedapat mungkin diambilkan dari bahan yang tersedia di sekitar, seperti batu dan pasir. Kecuali bahan bangunan yang berupa semen, besi untuk kerangka bangunan dan batu bata yang harus dibeli

\section{Penyaluran dan pendistribusian air}

Air dari mata air tersebut ditampung dalam bak penampung, selanjutnya air dialirkan ke konsumen. Penyaluran air dari penampung ke konsumen dilakukan melalui jaringan pipa. Sebelum ditemukan paralon (PVC) penyaluran air dilakukan dengan menggunakan bahan lokal berupa bambu, tetapi sekarang sebagian besar penyaluran air menggunakan paralon, dan selang plastik. Dalam penyaluran air menggunakan paralon sudah diperhitungkan kemiringan lerengnya serta jarak dari bak penampung ke konsumen. Oleh sebab itu, dari bak penampung pertama, air masih disalurkan dan ditampung di bak penampung berikutnya sebelum didistribusikan ke konsumen. Dari bak penampung yang terletak di bagian hilir ini, baru air didistribusikan ke konsumen dengan mengambil jalur terpendek. Ada kalanya sumber mata air terletak jauh di hulu, sehingga untuk menyalurkannya diperlukan pipa yang panjang. Dalam menentukan jalur pipa dicari jalur terpendek, disesuaikan dengan kondisi lapangan, bahkan harus melalui lereng curam dan melintasi lembah sungai (Gambar 5).

Apabila jaraknya sangat panjang, diperlukan beberapa tempat kontrol, karena apabila pipa yang disambung cukup panjang dan tidak ada tempat kontrol, besar kemungkinan ketika dialiri air dengan tekanan hidraulik yang besar pipa tersebut dapat pecah.

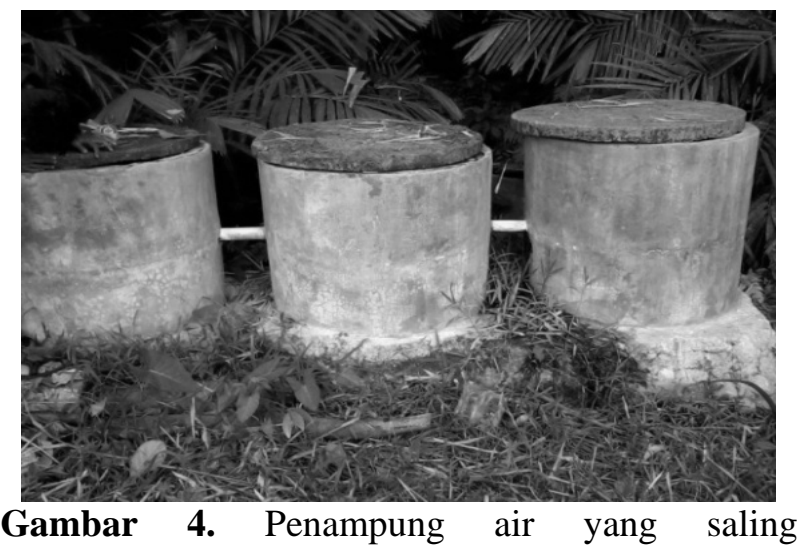

dihubungkan. 

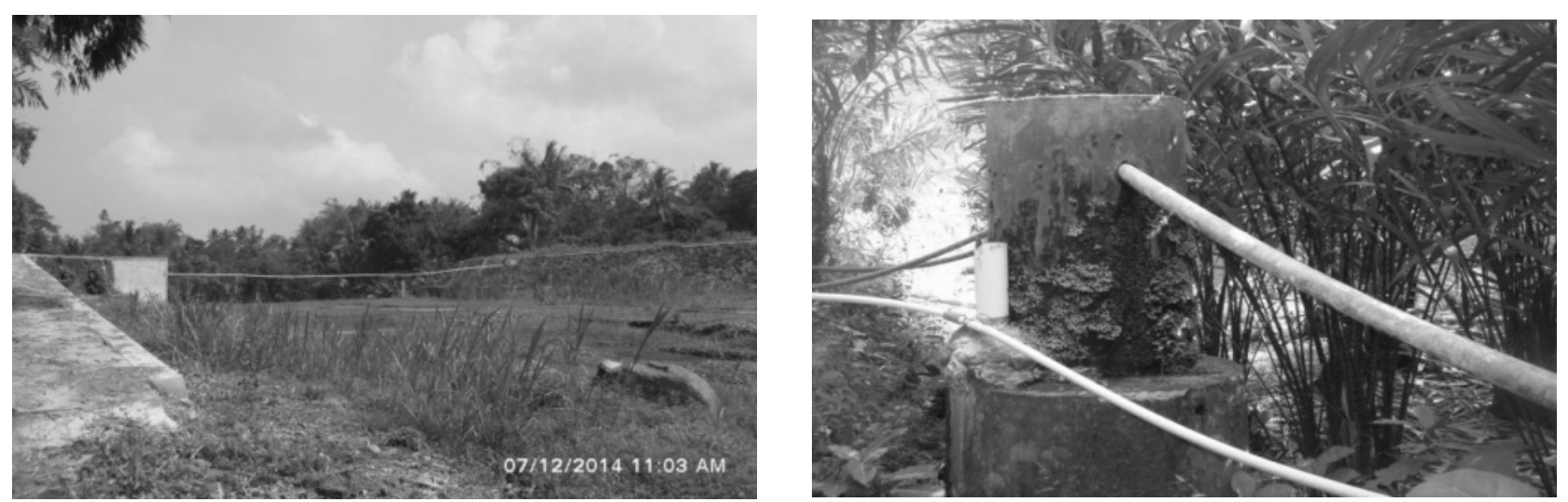

Gambar 5. Pendistribusian air dengan pipa paralon.

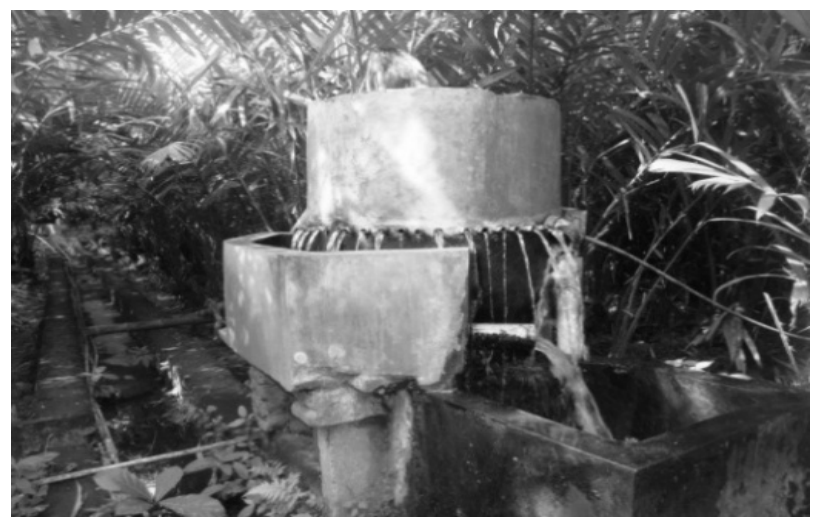

Gambar 6. Pemanfaatan teknologi pendistribusian air mata air berkeadilan.

\section{Pembagian air ke rumahtangga}

Masyarakat menghendaki untuk mendapatkan air yang cukup, namun seringkali keinginan tersebut belum tentu dapat terpenuhi. Air dari mata air didistribusikan ke konsumen secara berkeadilan. Teknik pendistribusian air dari mata air ke konsumen secara berkeadilan telah diterapkan oleh masyarakat dengan mendasarkan tekanan hidraulik yang sama yaitu dengan membuat lubang outlet pada bak penampung yang tingginya sama (Gambar 6). Dari lubang-lubang tersebut baru disalurkan menggunakan selang plastik ke konsumen. Dengan ketinggian yang sama, maka tekanan hidrostatis dari air akan sama, sehingga akan dihasilkan debit yang sama. Masyarakat yang memerlukan tinggal menyalurkan dari bak penampung tersebut dengan menyambungkan selang plastik ke rumah masingmasing. Di sinilah teknologi yang sederhana diterapkan. Teknologi ini mengaplikasikan prinsip berkeadilan di dalam mendapatkan air.

\section{Kearifan Lokal}

Bentuk-bentuk kearifan lokal yang sudah lama dilakukan oleh masyarakat dalam memanfaatkan sumber air yang berupa mata air diuraikan sebagai berikut.

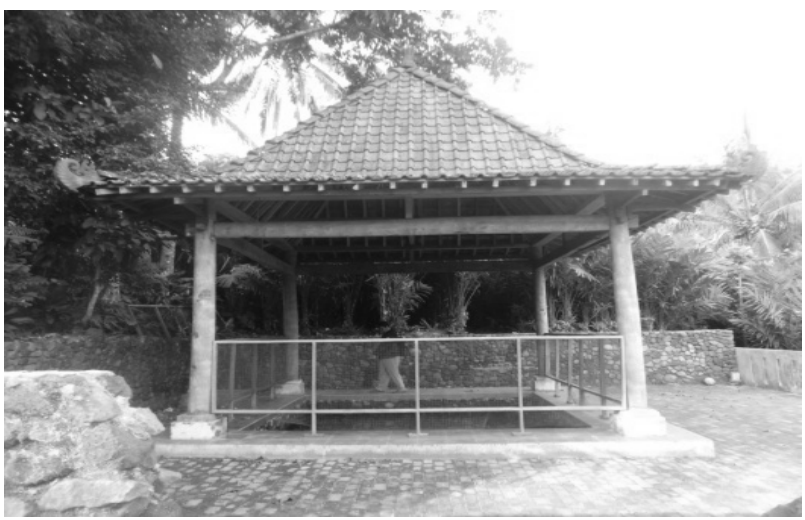

Gambar 7. Mata air dijadikan tempat sakral.

\section{Perlindungan dan pemeliharaan sumber mata air}

Pengelolaan air dari mata air sudah mulai terlihat dari pengelolaan sumber mata air. Tempat di mana mata air muncul dirawat dan dijaga kebersihannya, tumbuhan atau pohon penutup tetap dipelihara, agar suasana di tempat pemunculan mata air tetap sejuk. Seringkali tempat pemunculan mata air tersebut dikeramatkan, orang tidak boleh berbuat sesuatu yang tidak terpuji (Gambar 7). Hal ini dimaksudkan agar sumber mata air tersebut tetap terjaga kebersihannya. Teknologi sederhana digunakan dalam memelihara mata air. Air mata air tersebut dilindungi dengan menampung dan kadang menutupnya agar air mata air terhindar dari sesuatu yang dapat masuk ke dalamnya, sehingga mata air tersebut terhindar dari pencemaran.

Air yang ditampung dari mata air kemudian disalurkan dengan pipa pralon PVC ke arah hilir. Di daerah hilir air tersebut masih juga didistribusikan dengan adil. Air ditampung, kemudian dari penampung tersebut dengan pipa-pipa ukuran yang lebih kecil yang ditempatkan pada ketinggian yang sama air dapat didistribusikan dengan debit yang sama ke rumahtangga. Cara ini menunjukkan sifat kebersamaan dan keadilan dalam mendistribusikan air, sehingga setiap rumahtangga mendapatkan bagian yang sama. Prinsip kebersamaan inilah tanda 
atau penciri budaya lokal yang sudah ada secara turun-temurun di masyarakat Indonesia.

\section{Penyaluran air mata air}

Dalam membangun penampung air dan jaringan distribusi masyarakat bekerjasama dengan sistem gotongroyong. Untuk pemeliharaan, setiap keluarga menyisihkan sejumlah iuran, untuk memperbaiki bangunan yang rusak atau mengganti pipa-pipa yang pecah karena sesuatu hal. Segala masalah yang menyangkut pengelolaan air, dimusyawarahkan dalam pertemuan yang disebut dengan rembug desa.

Organisasi persatuan pemakai air di daerah penelitian menjadi wadah tempat mengorganisasikan pengelolaan air, termasuk menyelesaikan masalah yang terkait dengan air. Di sini terlihat adanya prinsip musyawarah mufakat yang menunjukkan budaya masyarakat.

\section{Penggunaan air}

Air mata air biasanya sangat bagus, air jernih, tawar dan menyejukkan. Dengan kualitas air yang bagus, maka prioritas pemanfaatan air mata air adalah untuk keperluan rumahtangga, sebagai air bersih. Penggunaan air untuk keperluan lainnya merupakan urutan selanjutnya seperti penggunaan untuk perikanan dan pertanian. Masyarakat telah menentukan prioritas pemanfaatan dengan memperhatikan debit mata air dan kualitasnya. Hal ini sudah secara turun-temurun dilakukan. Sedemikian baiknya kualitas air yang keluar dari mata air, seringkali masyarakat menganggap di dalam kepercayaannya bahwa mata air tersebut dapat digunakan untuk menyembuhkan berbagai macam penyakit, karena kualitas air mata air yang baik. Kadang-kadang mata air tertentu dapat mengandung zat kimia tertentu yang secara medis dapat menyembuhkan penyakit tertentu (Sudarmadji, 2013).

\section{Pengelolaan Mata Air}

Pengelolaan mata air tidak terbatas pada pemanfaatan air dari mata air, tetapi termasuk pencegahan terhadap perusakan dan pemeliharaan agar mata air tersebut dapat lestari digunakan masyarakat. Pengelolaan tidak hanya ditujukan bagi air mata air, tetapi juga terhadap sumbernya. Caracara pemanfaatannya serta teknologi yang digunakan dalam pemanfaatan serta pemeliharaan juga diperhatikan dalam pengelolaan mata air. Dari analisis data yang dilakukan dalam penelitian ini, maka model pengelolaan mata air disusun. Hal-hal yang dijadikan dasar penyusunan model pengelolaan mata air adalah pada uraian berikut.

\section{Karakteristik mata air}

Karakteristik mata air yang diperhatikan dan dipertimbangkan adalah: letak pemunculan mata air (posisi mata air), debit mata air, kualitas air mata air. Posisi pemunculan mata air menentukan bagaimana masyarakat menampung airnya untuk didistribusikan ke konsumen. Mata air yang muncul di tebing sungai (lembah sungai) berbeda cara pengumpulan airnya dengan mata air yang terletak di tekuk lereng. Posisi mata air menentukan pembuatan jaringan distribusi air ke konsumen. Debit mata air menentukan bentuk dan ukuran menampung air sebelum didistribusikan ke konsumen. Debit mata air juga menentukan jenis penggunaan sesuai dengan prioritas pemanfaatan. Air dari mata air lebih diprioritaskan untuk penyediaan air rumahtangga daripada penggunaan yang lain, seperti irigasi dan perikanan. Debit mata air juga akan menentukan kemampuan pelayanan air.

\section{Jenis penggunaan air}

Air mata air dimanfaatkan untuk berbagai keperluan sehingga dalam pengelolaan mata air; dipertimbangkan penggunaan air berdasarkan prioritasnya yaitu untuk: keperluan rumahtangga/domestik, pertanian/irigasi, perikanan dan keperluan lainnya.

Air yang diperoleh dari mata air dapat langsung dimanfaatkan di tempat munculnya mata air, atau dapat juga dengan menyalurkan air mata air ke rumahnya. Mata air yang debitnya relatif besar bahkan digunakan untuk memenuhi air rumahtangga di daerah hilir. Kebutuhan air untuk mandi dan mencuci dapat dilakukan di tempat pemunculan mata air. Untuk memenuhi kebutuhan air irigasi, air dari mata air disalurkan ke arah hilir dengan saluran yang dibuat, dan dialirkan ke tempat yang memerlukan.

Untuk memenuhi kebutuhan perikanan air dari mata air yang disalurkan untuk keperluan irigasi sebagian disalurkan ke kolam ikan. Kolam ikan di daerah penelitian biasanya tidak terlalu besar, sehingga tidak banyak membutuhkan air. Kebutuhan air tersebut dipenuhi dengan tidak mengganggu peruntukan yang lain.

\section{Ketersediaan dan penguasaan teknologi}

Untuk membuat bak penampung air yang keluar dari mata air, menyalurkannya ke konsumen dan mendistribusikan secara berkeadilan kepada konsumen diperlukan penguasaan teknologi. Letak dan posisi mata air yang jauh memerlukan sistem perpipaan untuk menyalurkan air ke konsumen. Diperlukan perencanaan dalam pembuatan penampung air dan penentuan jalur untuk memasang 


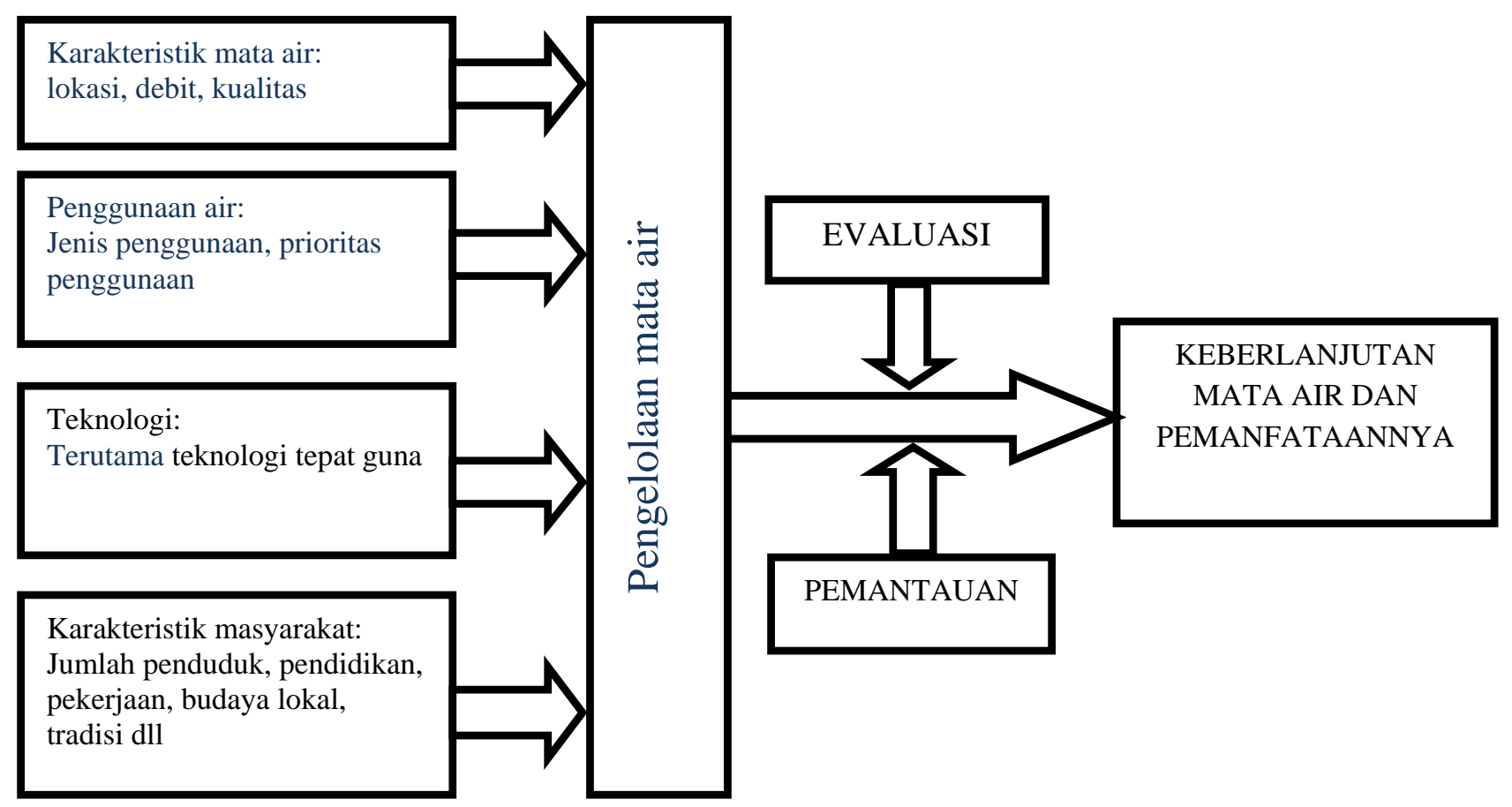

Gambar 8. Pengelolaan mata air berdasarkan teknologi dan klarifan lokal (Sudarmadji dkk., 2014).

jaringan pipa. Dalam membuat penampung air juga diperlukan perencanaan yang baik, termasuk bahan, bentuk dan ukuran penampung air. Bahan yang digunakan dicari bahan yang baik, agar awet. Bahan yang digunakan diambil dari tempat sekitarnya, dikerjakan secara gotong-royong. Dalam mendistribusikan air ke konsumen secara berkeadilan harus direncanakan dengan sebaikbaiknya agar tidak menimbulkan masalah. Semuanya tidak terlepas dari penguasaan teknologi masyarakat setempat.

\section{Karakteristik masyarakat}

Masyarakat sebagai subyek dalam pengelolaan mata air, karena masyarakat yang akan mendapatkan manfaat dari pengelolaan air tersebut dan juga yang melakukan dalam pengelolaan air. Karakteristik yang dipertimbangkan secara garis besar adalah jumlah penduduk; tingkat pendidikan, pekerjaan dan penghasilan, dan budaya masyarakat setempat.

Jumlah penduduk mempengaruhi jumlah air yang digunakan dan aktivitas penduduk menyediakan tenaga dalam pengelolaan mata air. Jumlah sambungan pipa air ditentukan oleh jumlah penduduk (terutama jumlah keluarga). Tingkat pendidikan, pekerjaan dan penghasilan berpengaruh terhadap partisipasi dalam pengelolaan mata air. Penghasilan menentukan kontribusi dalam bentuk uang pada pelaksanaan pengelolaan mata air. Budaya masyarakat menentukan kebersamaan dan keberlanjutan di dalam pengelolaan mata air dan termasuk pemeliharaan sarana penampung air, perpipaan dan keberlangsungan dalam pemeliharaan sumber mata air. Model pengelolaan mata air ditunjukkan pada Gambar 8.

Model pengelolaan mata air merupakan model integrasi pengelolaan mata air yang memadukan antara teknologi dan kearifan lokal, dengan mempertimbangkan karakteristik mata air, karakteristik penggunaan atau pemanfaatan air, ketersediaan teknologi dan karakteristik masyarakat, termasuk budaya dan kearifan lokal. Dalam pelaksanaannya, model tersebut harus dipantau, dan dievaluasi oleh masyarakat sendiri. Apabila di dalam pelaksanaannya ternyata model tersebut tidak atau kurang berhasil seperti yang diharapkan, maka harus dilakukan perbaikan. Pada prinsipnya model tersebut dimaksudkan untuk menjaga kesinambungan dan berkelanjutan mata air. Keberlanjutan yang dimaksud dapat ditinjau dari kuantitas, kualitas airnya maupun keberlanjutan dari sisi pemanfaatan dan kemanfaatan mata air tersebut

\section{KESIMPULAN}

Mata air merupakan sumber penyediaan air yang sinambung dibandingkan dengan air sungai, sehingga musim kemarau kebanyakan air sungai sudah berkurang jauh debitnya, sedangkan air tanah dan mata air masih tersedia dengan cukup. Dalam memanfaatkan mata air diperlukan teknologi, yang secara turun-temurun telah dilakukan masyarakat, berbekal dari pengetahuan dan pengalaman yang dimiliki, sehingga mata air tetap terpelihara dengan baik, karena mata air relatif lebih sinambung dalam penyediaan air. Secara sadar masyarakat telah dapat 
mengintegrasikan antara kearifan lokal yang dimiliki sejak lama dengan teknologi, terutama teknologi yang bersifat tepat guna. Integrasi pengelolaan mata air memadukan antara karakteristik mata air, karakteristik masyarakat, penguasaan teknologi dan budaya masyarakat setempat.

Mengingat pemanfaatan air dari mata air semakin kompleks, perlu dipertahankan kearifan lingkungan yang sudah ada, terutama pada generasi muda agar nilai-nilai kearifan lingkungan tidak semakin memudar. Perlu diterapkan peraturan yang jelas terhadap pemanfaatan air dari mata air untuk keperluan di luar keperluan rumahtangga, agar di kemudian hari tidak menimbulkan konflik pemanfaatan air mata air tersebut.

\section{UCAPAN TERIMAKASIH}

Ucapan terimakasih disampaikan kepada Direktur dan Wakil Direktur Sekolah Pascasarjana Universitas Gadjah Mada yang telah memberikan kesempatan dalam melaksanakan Hibah Sekolah Pascasarjana untuk melaksanakan penelitian ini dengan No Kontrak 1096/H1.SPs/PL/2014. Ucapan terimakasih juga disampaikan kepada kepada Staf Laboratorium Hidrologi dan Kualitas Air Fakultas Geografi Universitas Gadjah Mada disampaikan ucapan terimakasih yang telah membantu malaksanakan uji kualitas air.

\section{DAFTAR PUSTAKA}

Fan, L., Liu, G., Wang, F., Ritsema, C.J., dan Giessen, V., 2014. Domestic Water Consumtion under Intermittent and Continous
Modes of Water Supply. Water Resources Management Journal Online, 28 : 853 - 865.

Randall, A., 1982. Resources Economic, an Economic Approach to Natural Resources and Environment Policy. Illinois.

Siswadi, Taruna, T., dan Purnaweni, H., 2011. Kearifan Lokal dalam Melestarikan Mata Air (Studi Kasus di Desa Purwogondo, Kecamatan Boja, Kabupaten Kendal). Jurnal Ilmu Lingkungan, 9(2):63-68.

Sudarmadji, Suprayogi, S., dan Setiadi, 2010. Konservasi Mata air Berbasis Masyarakat di Kabupaten Gunungkidul untuk Mengantisipasi Dampak Perubahan Iklim. Laporan Penelitian. Sekolah Pascarajana UGM, Yogyakarta.

Sudarmadji, Suyono, dan Darmanto, D. 2012. Pengelolaan Sumberdaya Air Berbasis Kearifan Lokal Masyarakat Pedesaan di Daerah Fisiografi Gunungapi dan Daerah Fisiografi Karst. Laporan Penelitian. Sekolah Pascasarjana UGM, Yogyakarta.

Sudarmadji, 2013. Mata Air: Perspektif Hidrologis dan Lingkungan. Sekolah Pascasarjana, UGM, Yogyakarta.

Sudarmadji, Darmanto, D., Widyastuti, M., dan Lestari S., 2014. Integrasi Taknologi dan Kearifan Lokal dalam Pengelolaan Mata Air untuk Penyediaan Air Rumahtangga Berkelanjutan. Laporan Penelitian. Sekolah Pascasarjana UGM. Yogyakarta

Todd, D.K., 1980. Ground Water Hydrology. John Willey and Sons, Inc., New York.

Todd, D.K., dan Mays, L.W., 2005. Groundwater Hydrology, 3rd ed. John Wiley and Sons, London. 